\title{
UNEXPECTED FAUNISTIC RECORDS OF RHACOCLEIS ANNULATA, EYPREPOCNEMIS PLORANS, AND XYA PFAENDLERI (ORTHOPTERA) FROM CROATIA AND SLOVENIA
}

\author{
Sebastian Ćato $^{1}$ \& Dean Zagorac ${ }^{2}$ \\ ${ }^{1}$ Srednja strukovna škola Šibenik, Ante Šupuka 31, Šibenik HR-22000, Croatia \\ (E-mail: cato11224@gmail.com) \\ ${ }^{2}$ Ulica bratov Mivšek 23, Borovnica SLO-1353, Slovenia (E-mail: dean.zagorac@gmail.com)
}

Ćato, S. \& Zagorac, D.: Unexpected faunistic records of Rhacocleis annulata, Eyprepocnemis plorans, and Xya pfaendleri (Orthoptera) from Croatia and Slovenia. Nat. Croat., Vol. 30, No. 2, 501-511, 2021, Zagreb.

Interesting records of one bush-cricket and two grasshopper species are reported from Croatia and Slovenia. Rhacocleis annulata Fieber, 1853 (Tettigoniidae: Tettigoniinae) has been reported for the first time from Croatia (Dubrava by Šibenik), as well as for Slovenia (Borovnica SW of Ljubljana); Eyprepocnemis plorans (Charpentier, 1825) (Acrididae: Eyprepocnemidinae) is reported for the first time for Croatia, also from Dubrava; and finally, the Xya pfaendleri Harz, 1970 (Tridactylidae: Tridactylinae) record from Dubrava represents the first record of this species from Dalmatia. Rhacocleis annulata and Eyprepocnemis plorans are known to be spreading through Europe, so these records contribute to the understanding of their dispersal in Southern Europe. Croatian Orthopteran fauna now counts, with two species added, 187 species, while Slovenian Orthopteran fauna now counts, with one species added, 158 species.

Key words: Rhacocleis annulata, Eyprepocnemis plorans, Xya pfaendleri, Dalmatia, Dubrava by Šibenik, Borovnica, dispersal, allochthonous species

Ćato, S. \& Zagorac, D.: Neočekivani faunistički nalazi Rhacocleis annulata, Eyprepocnemis plorans i Xya pfaendleri (Orthoptera) iz Hrvatske i Slovenije. Nat. Croat., Vol. 30, No. 2, 501-511, 2021, Zagreb.

Rad predstavlja zanimljive nalaze jedne vrste konjica i dviju vrsta skakavaca iz Hrvatske i Slovenije. Mramorni konjic grmušar Rhacocleis annulata Fieber, 1853 (Tettigoniidae: Tettigoniinae) po prvi je put zabilježen za Hrvatsku u Dubravi kraj Šibenika, a za Sloveniju u Borovnici sjeverozapadno od Ljubljane; plavonogi uplakani skakavac Eyprepocnemis plorans (Charpentier, 1825) (Acrididae: Eyprepocnemidinae) po prvi je put zabilježen za Hrvatsku također u Dubravi; i naposljetku nalaz crnog buhoskakavca (Xya pfaendleri Harz, 1970; Tridactylidae: Tridactylinae) u Dubravi prvi je nalaz ove vrste u Dalmaciji. Poznato je da se Rhacocleis annulata i Eyprepocnemis plorans šire Europom, tako da naši nalazi doprinose poznavanju širenja ovih vrsta po južnoj Europi. Hrvatska fauna ravnokrilaca sada, s dvjema novim vrstama, broji 187 vrsta, a slovenska fauna ravnokrilaca s jednom novom vrstom broji ukupno 158 vrsta.

Ključne riječi: Rhacocleis annulata, Eyprepocnemis plorans, Xya pfaendleri, Dubrava kraj Šibenika, Borovnica, širenje, alohtone vrste

\section{INTRODUCTION}

The Western Balkans is among the most diverse areas of Europe from the standpoint of Orthoptera diversity (HochкiRch et al., 2016a). Croatian orthopteran fauna counts 185 species (Skejo et al., 2018; STAlling et al., 2021), while the Slovenian com- 
prises 157 species (Gomboc \& Š EGULA, 2014). For now, no alien grasshoppers or crickets have been reported to have arrived in Croatia or Slovenia in the last few decades (e.g., Skejo et al., 2018 reported only old records of the cave cricket Tachycines asynamorus Adelung, 1902 from Dalmatia, but no known populations). Because of the previous general lack of entomological research in the Balkans, new faunistic records and discoveries of new species can be expected in the future. It is even more likely considering that many native European Orthoptera (HolušA et al., 2014; PAvlović, 2019; KALÁB et al., 2021) are migrating northwards with global warming and even managing to establish populations in unexpected areas (MONNERAT et al., 2020). Some exotic Orthoptera (Żurawlew et al., 2020) and Mantodea (van der Heyden, 2021) have arrived to Europe as well, sometimes establishing populations (VuJIĆ et al., 2021; Martinović et al., under review), and sometimes not (e.g., REINHARDT \& KöHLER, 2014 reported Acanthacris ruficornis (Fabricius, 1787) in a flower shop in Germany). There is a curious case of Phlugiola dahlemica (Eichler, 1938), a species belonging to a South American genus. It was originally described from the Botanical Garden Berlin-Dahlem, and its true distribution is not known to this day (HARZ, 1969).

In this study, three Orthoptera species are reported from unexpected places. Tunisia-, Sicily- and Italy-endemic Rhacocleis annulata Fieber, 1853 is reported from the Garden Center in Dubrava by Šibenik (Croatia) and from a garden in Borovica near Ljubljana (Slovenia). Furthermore, Eyprepocnemis plorans (Charpentier, 1825) and Xya pfaendleri Harz, 1970 are reported from the Garden Center in Dubrava, as well.

\section{MATERIAL AND METHODS}

Most of the observations were originally uploaded to iNaturalist (Tab. 1), where they were identified by grasshopper specialists (Josip Skejo and Niko Kasalo). The identifications were later re-checked and confirmed using relevant keys (BELLMANN et al., 2019; HARz, 1969, 1975; MASSA et al., 2013). Photographs of living specimens were uploaded to iNaturalist (altogether 7 specimens belonging to $R$. annulata (2 observa-

Tab. 1. Links to all the observations reported in this study and uploaded to iNaturalist. Abbreviations: $\mathrm{N}$-number of the record, L-locality, obs.-observation, A-Borovnica, Slovenia, B-Dubrava, Croatia.

\begin{tabular}{|c|c|c|c|c|c|}
\hline $\mathbf{N}$ & Species & Specimens & $\mathbf{L}$ & Obs. date & iNaturalist link \\
\hline 1 & Rhacocleis annulata & an adult $\hat{\delta}$ & A & 05.XI.2020. & $\begin{array}{c}\text { inaturalist.org/ } \\
\text { observations /64978025 }\end{array}$ \\
\hline 2 & Rhacocleis annulata & an adult $\hat{\delta}$ & B & 25.VIII.2021. & $\begin{array}{c}\text { inaturalist.org/ } \\
\text { observations/93058972 }\end{array}$ \\
\hline 3 & Eyprepocnemis plorans & $\begin{array}{l}\text { a young } \\
\text { nymph }\end{array}$ & B & 12.VII.2021. & $\begin{array}{c}\text { inaturalist.org/ } \\
\text { observations/91415672 }\end{array}$ \\
\hline 4 & Eyprepocnemis plorans & $\begin{array}{l}\text { last instar } \\
\text { nymph }\end{array}$ & B & 21.VIII.2021. & $\begin{array}{c}\text { inaturalist.org/ } \\
\text { observations/93046101 }\end{array}$ \\
\hline 5 & Eyprepocnemis plorans & an adult $\hat{\partial}$ & B & 26.VIII.2021. & $\begin{array}{c}\text { inaturalist.org/ } \\
\text { observations/93060690 }\end{array}$ \\
\hline 6 & Eyprepocnemis plorans & $\begin{array}{l}\text { last instar } \\
\text { nymph }\end{array}$ & B & 28.VIII.2021. & $\begin{array}{c}\text { inaturalist.org/ } \\
\text { observations /93060747 }\end{array}$ \\
\hline 7 & Eyprepocnemis plorans & $\begin{array}{l}\text { last instar } \\
\text { nymph }\end{array}$ & B & 31.VIII.2021. & $\begin{array}{c}\text { inaturalist.org/ } \\
\text { observations/98101199 }\end{array}$ \\
\hline 8 & Xya pfaendleri & an adult & B & 17.VIII.2021. & $\begin{array}{c}\text { inaturalist.org/ } \\
\text { observations/91555575 }\end{array}$ \\
\hline
\end{tabular}


tions), E. plorans (5), and X. pfaendleri (1)), and more specimens were collected in Dubrava Garden Center by Šibenik for examination and photography of the morphological details. All the specimens originate from two localities, (i) a garden in Borovnica by Ljubljana in Slovenia $\left(45^{\circ} 55^{\prime} 16.7^{\prime \prime} \mathrm{N}, 14^{\circ} 21^{\prime} 48.4^{\prime \prime} \mathrm{E}\right)$ (A in Tab. 1), and (ii) Dubrava by Šibenik in Dalmatia, Croatia $\left(43^{\circ} 73^{\prime} 60.5^{\prime \prime} \mathrm{N}, 15.94^{\prime} 70.8^{\prime \prime} \mathrm{E}\right)$ (B in Tab. 1).

\section{RESULTS}

family Tettigoniidae

subfamily Tettigoniinae

Rhacocleis annulata Fieber, 1853,

ringed bush-cricket,

Croatian: mramorni konjic grmušar

Slovenian: obročkasta slamnica

(Fig. 1)

\section{Material examined:}

SLOVENIA: One live male, Borovnica SW of Ljubljana $\left(45^{\circ} 55^{\prime} 16.7^{\prime \prime} \mathrm{N}\right.$, $14^{\circ} 21^{\prime} 48.4^{\prime \prime}$ ) 5.XI.2020. obs. D. Zagorac; CROATIA: six collected specimens, three females and three males, Dubrava near Šibenik $\left(43^{\circ} 73^{\prime} 66.4^{\prime \prime} \mathrm{N}, 15^{\circ} 94^{\prime} 73.6^{\prime \prime} \mathrm{E}\right) 31$. VIII.2021. leg. S. Ćato; about ten live specimens (nymphs and adults; males and females) were seen, Dubrava near Šibenik (43.73'59.3' $\left.\mathrm{N}, 15.94^{\prime} 70.0^{\prime \prime} \mathrm{E}\right)$ 25. VIII.-5. IX.2021. obs. S. Ćato.

\section{Distribution in Croatia and Slovenia}

In Croatia, only a population from Dubrava by Šibenik is known (the Mediterranean, Adriatic region: Dalmatia), while from Slovenia, a single specimen was reported from Borovnica near Ljubljana (this study).

\section{Distribution in Europe}

Rhacocleis annulata is endemic to Tunisia, Sicily and southern Italy (MAssa et al., 2013), but it has occupied parts of France (BARDET \& Boitier, 2006), the Netherlands, the United Kingdom, Switzerland (Monnerat et al., 2020) and Austria (Essl \& ZunAKRATкY, 2021), where it is considered an alien species. For the annotated distribution, please refer to Fig. 4.

\section{Similar species}

This Rhacocleis species is similar to its congeners R. germanica (Herrich-Schäffer, 1840) and R. buchichii Herman, 1974. It is, however, easily separated from the two by colouration (black hind knees, Fig. 1A,B,J); shape of cerci in males (Fig. 1D, shorter than in R. buchichii, with smaller inner teeth than $R$. germanica); shape of subgenital plate in females (Fig. 1F,G, square with typical U-shaped excision and two depressions; compare Fig. 1F,G to square-shaped subgenital plate without excision and with a median ridge in $R$. buchichii in PAvLović et al., 2020 and in Felix et al., 2020; and compare to elongated subgenital plate with a small apical excision in $R$. germanica in Massa et al., 2013). Colouration can sometimes be similar in R. buchichii (compare with WAgner, 2015 and Felix et al., 2020). 

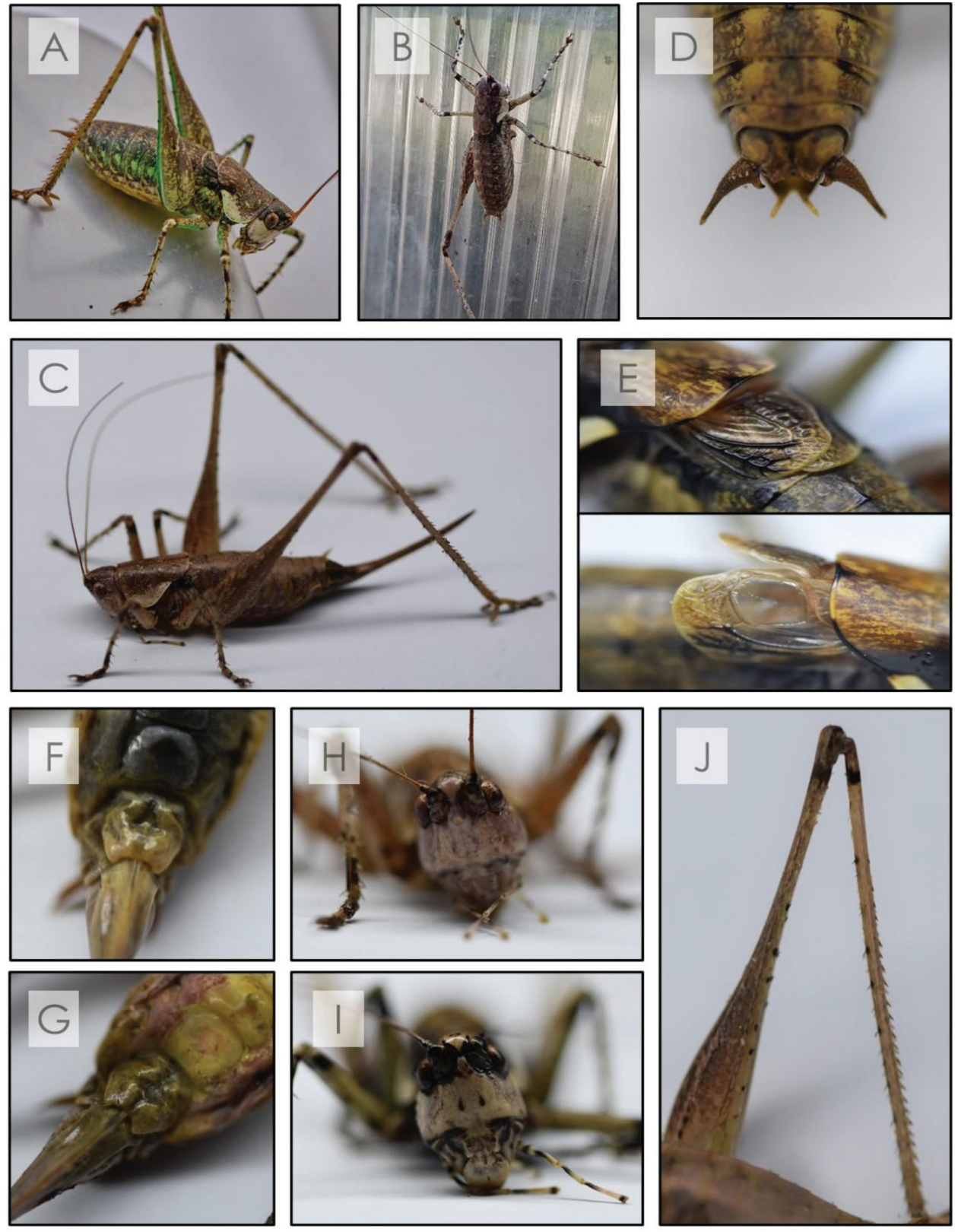

Fig. 1. First records of Rhacocleis annulata from Slovenia and Croatia. A) living male from Slovenia, B) living male from Croatia, C) female from Croatia, D) male cerci, E) male tegmina, F) and G) female subgenital plates, H) and I) head in frontal view, J) detail of the hind leg. Photo S. Ćato. 


\section{Notes}

This is the first record of this alien species for Croatia, as it is for Slovenia. The species lacks a Croatian name, thus herewith, we propose "mramorni konjic grmušar", because of its marble colouration (Croatian: mramorna) and Croatian names of other Rhacocleis species (Croatian: konjici grmušari) (Skejo et al., 2018).

\section{family Acrididae}

subfamily Eyprepocnemidinae

Eyprepocnemis plorans (Charpentier, 1825),

Croatian: plavonogi uplakani skakavac

(Fig. 2)

\section{Material examined:}

Three collected specimens, two adults (male and female) and one last instar nymph (female). Dubrava near Šibenik (43.73'59.3'”N, 15.94'70.0'E) 24. VIII.-28.VIII 2021. leg. S. Ćato; around six live specimens (nymphs and adults; males and females) were seen in Dubrava near Šibenik $\left(43.73^{\prime} 59.3^{\prime \prime} \mathrm{N}, 15.94^{\prime} 70.0^{\prime \prime} \mathrm{E}\right) 2021$. obs. S. Ćato.

\section{Distribution in Croatia}

In Croatia, only a population from Dubrava by Šibenik is now known (the Mediterranean, Adriatic region: Dalmatia) (this study).

\section{Distribution in Europe}

The Lamenting Grasshopper inhabits Mediterranean Europe but does not reach the northern shores of the Mediterranean Sea (absent from the French and most of the Italian coast, also absent from the shores of the Adriatic Sea and Black Sea) (MAssa et al., 2013; HонскіrсH et al., 2016). For example, in Italy, the species is abundant in Sardinia and Sicily, while rare in the mainland (MASsA et al., 2013). The species is common in coastal marshy habitats, orchards, and dunes with high vegetation (MASSA et al., 2013). For the annotated distribution, please refer to Fig. 4.

\section{Similar species}

Because of the striped eyes (Fig. 2D) this species is visually similar to Anacridium aegyptium (Linnaeus, 1764), from which it is easily separated by smaller size and more flashy colours (e.g., blue hind tibiae). It is also similar to Calliptamus italicus (Linnaeus, 1758) in general colouration, but it can be easily distinguished from the latter by the blue hind tibiae and larger size.

\section{Notes}

This is the first record of this species from Croatia. The species lacks a Croatian name, thus herewith, we propose "plavonogi uplakani skakavac". The first word refers to its blue hind tibiae (Croatian: plave noge), the second word refers to dark marking on the grasshopper's genae, reminiscent of crying (Croatian: plakati), and the last word is grasshopper (Croatian: skakavac). 

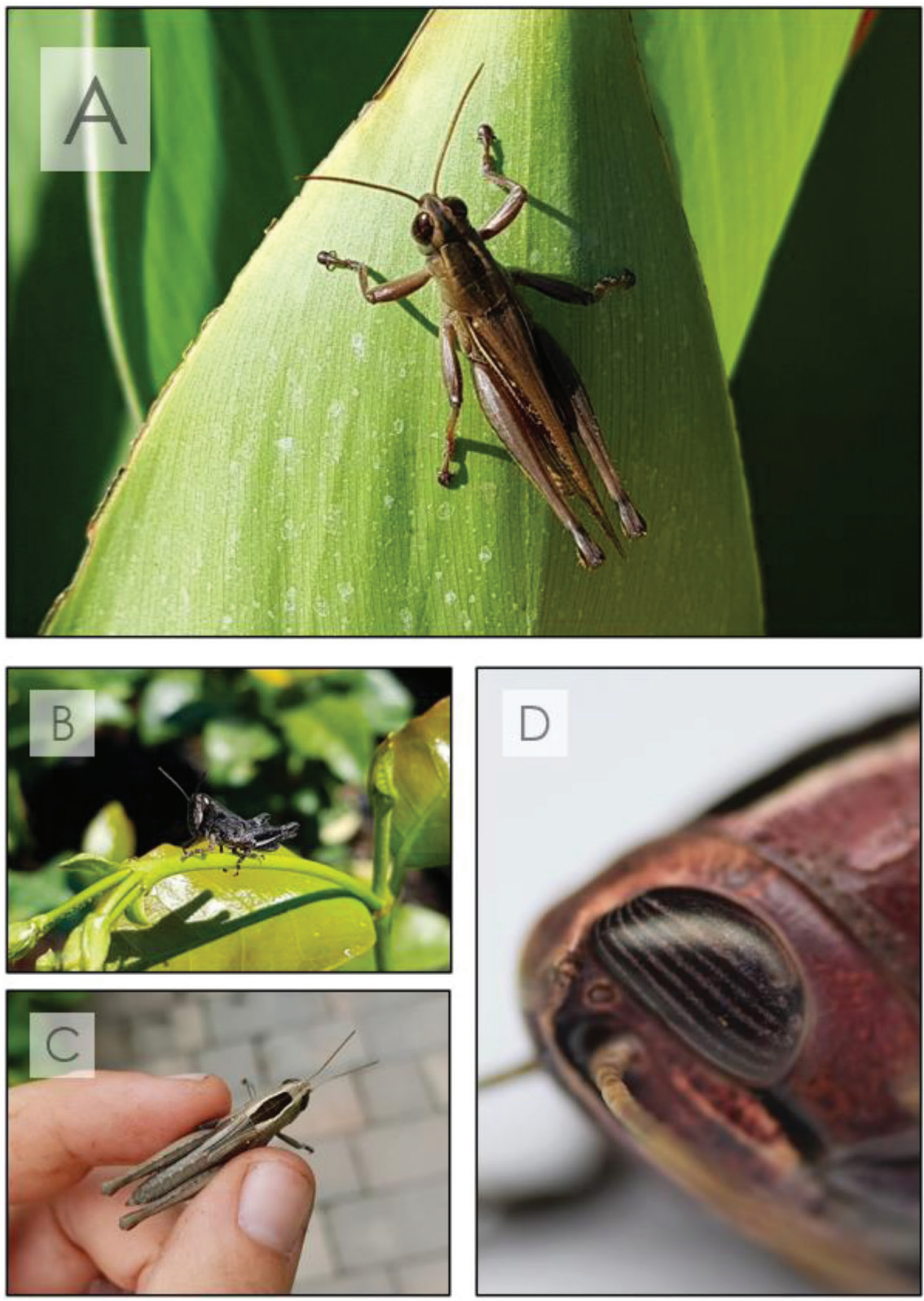

Fig. 2. First records of Eyprepocnemis plorans from Croatia. A) Adult male, B) Young nymph, C) Last instar nymph, D) Eye-macro. Dubrava by Šibenik, Dalmatia, Croatia. Photo S. Ćato. 
family Tridactylidae

subfamily Tridactylinae

Xya pfaendleri Harz, 1970, hr. crni buhoskakavac

(Fig. 3)

\section{Material examined:}

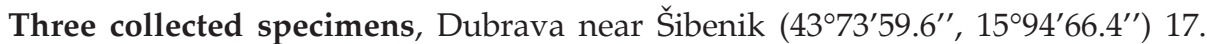
VIII.2021. leg. S. Ćato; around 10 live specimens were observed, Dubrava near Šibenik (437 $\left.73^{\prime} 59.6^{\prime \prime}, 15^{\circ} 94^{\prime} 66.4^{\prime \prime}\right) 19$. VIII.2021.

\section{Distribution in Croatia}

The species was known previously in Croatia only from the Pannonian region (SkEJo et al., 2018), from where it was reported in 2012 for the first time (Szövényi \& Puskás, 2012), so with this record, the known distribution of X. pfaendleri in the country is expanded to the Mediterranean, Adriatic region: Dalmatia.
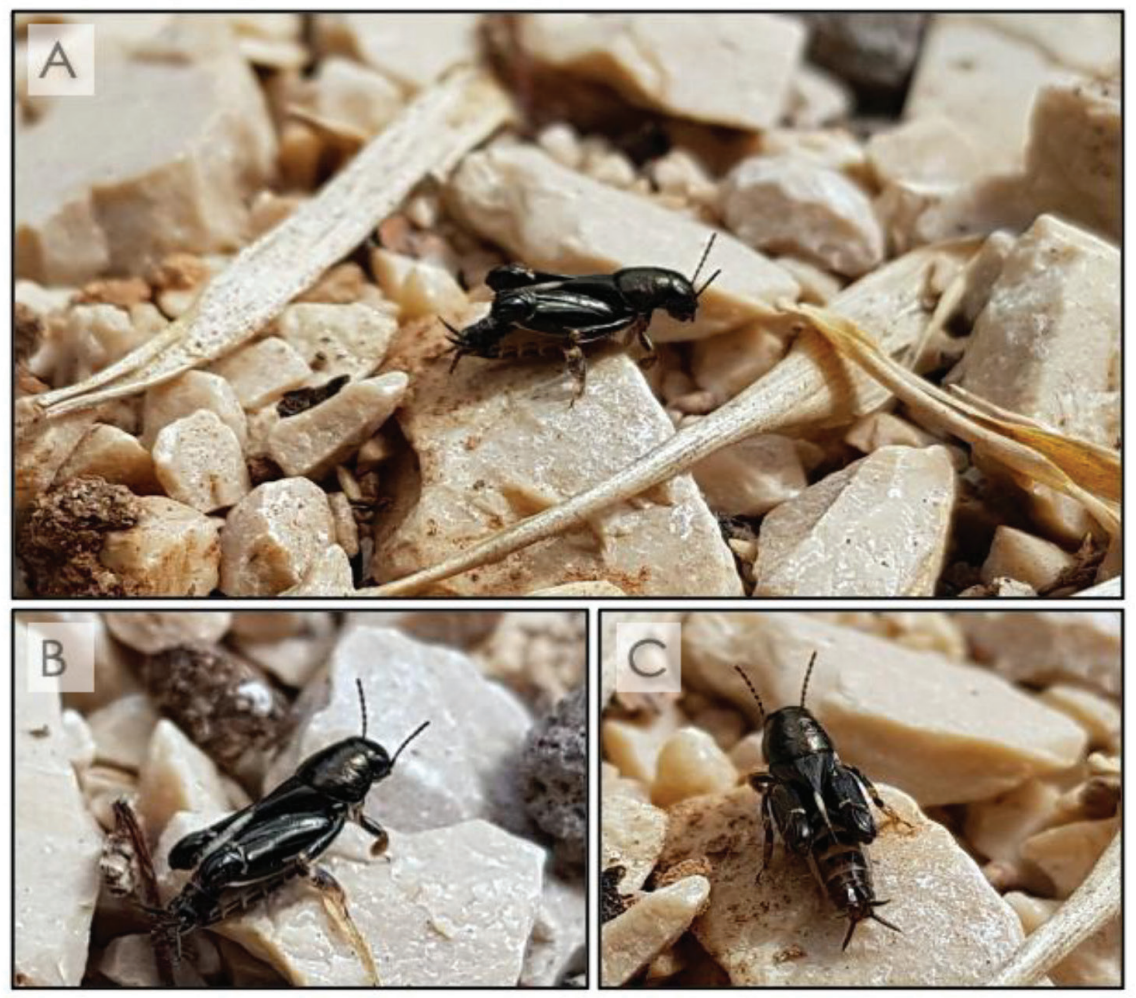

Fig. 3. First record of Xya pfaendleri from Dubrava by Šibenik, Dalmatia, Croatia. A) lateral view, B) dorsolateral view, and C) dorsal view. Photo S. Ćato. 


\section{Distribution in Europe}

The species inhabits large areas from the Eastern Mediterranean island of Cyprus to Czechia in the North, and from Slovenia in the west to Ukraine in the east (HocHKIRCH et al., 2016a). For the annotated distribution, please refer to Fig. 4.

\section{Similar species}

The species is similar to Xya variegata (Latreille, 1809), the only other false molecricket known to inhabit Croatia. Distinguishing it from X. variegata, which has a yellow marking on the paranota, the lateral lobes of the pronotum of $X$. pfaendleri are completely black (Fig. 3A, B).

\section{DISCUSSION}

In recent years, there is ample evidence that native European grasshopper species are extending their distribution ranges within Europe, and alien species have established population(s) in European countries (e.g., EssL \& ZunA-KraTKY, 2021).

A good example is $R$. annulata, $a$ species that has already been reported to have been spreading into the other countries close to its native range (MONNERAT et al., 2020; EssL \& ZunA-KratKy, 2021). In Croatia, many adult individuals and last instar nymphs were observed in the greenhouses (Vrtni Centar Dubrava) or in the vegetation near them (e.g., Canna sp.). The presence of different stages at the locality suggests the species has an established population in Croatia. A single specimen record from Slovenia raises the question of whether the species has established a population in that country as well. In Dubrava, variation in colouration has been observed among the individuals of this species. For example, some had more green-and-white markings (males, some females), while other females had yellowish-brown colours (Fig. 1A, B, C). Also, the colouration pattern of the head was observed to vary within the population (Fig. 1H, I).

The next species of interest is $\boldsymbol{E}$. plorans, with individuals of this species having been found taking shelter, like the previous species, in Canna sp. (Fig. 2A). Some nymphs were, however, also found in low growing vegetation nearby (Fig. 2B). Again, the presence of both nymphs and adults implies there is an established population of this species at the Garden centre in Dubrava.

Dubrava by Šibenik is a somewhat unusual place to find X. pfaendleri. This is the first record of this eastern European and Middle Eastern species (HochKIRCH et al., 2016a, 2016c, see Fig. 4) in Dalmatia. Pannonian localities inhabited by this species usually have natural water sources, while the newly recorded locality is rather dry, especially during the long and hot summer months. Thus, the species here lives in close proximity to the irrigation system. The irrigation for the plants has arguably helped the population to establish itself regardless of the natural climate. The species has been observed in leaf litter under bamboo plants together with Tetrix ceperoi (Bolívar, 1887). High moisture is present at the spot, so both genera (Xya and Tetrix) have the required conditions to live in.

Both $R$. annulata and E. plorans have highly likely been introduced into the garden centre with the imported plant material. It seems reasonable to believe so because the plant material is mainly imported from Italy, one of the locations being Sicily (which 

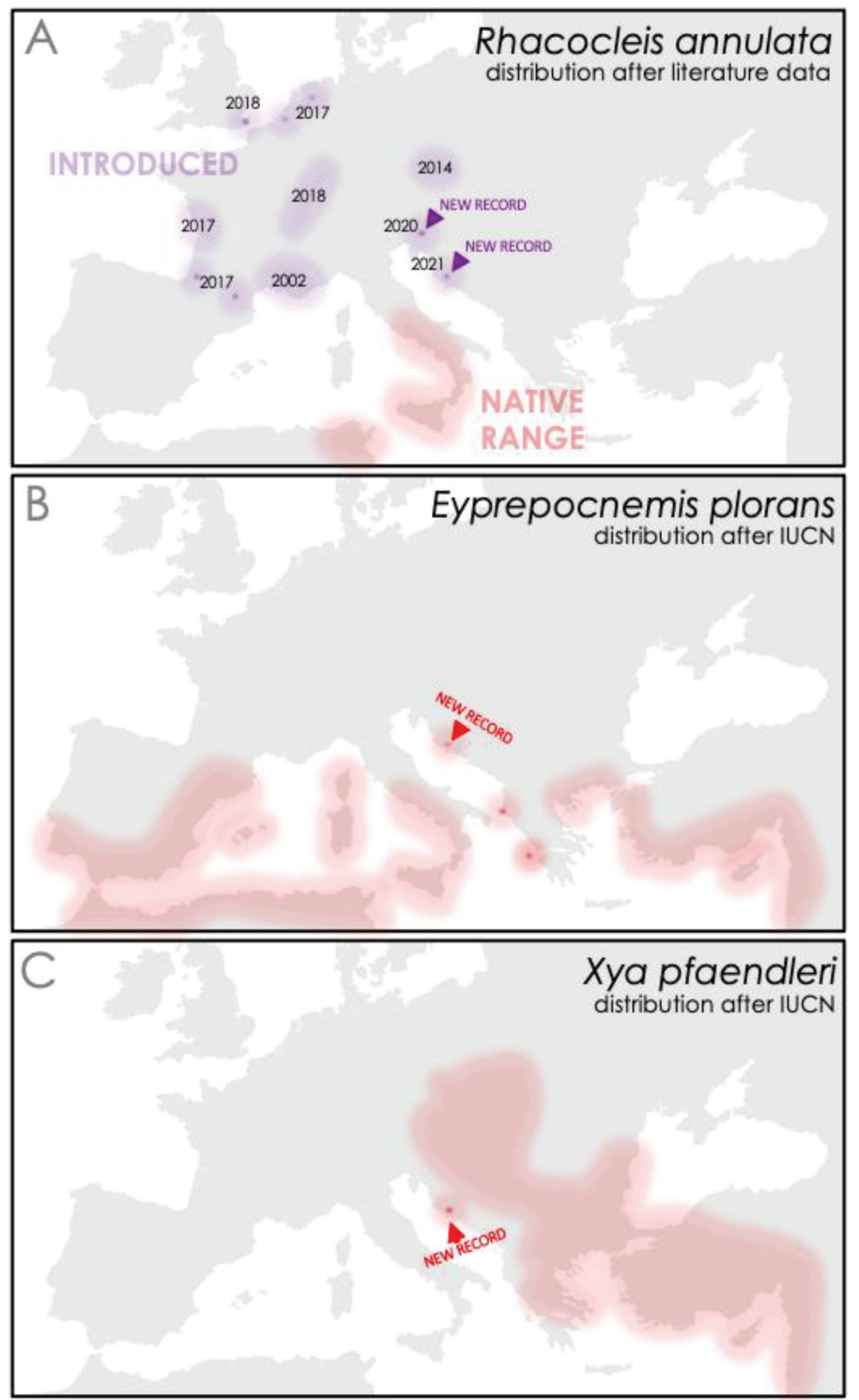

Fig. 4. Annotated distribution of A) Rhacocleis annulata, B) Eyprepocnemis plorans, and C) Xya pfaendleri in Europe. Distribution maps follow IUCN Red List (НоснкіRсн et al., 2016a), and for Rhacocleis annulata literature data (BARDET \& Boitier, 2006; Essl \& Zuna Kratky, 2021; Monnerat et al., 2020). Maps drawn by J. Skejo. 
is the native area for both Rhacocleis annulata and Eyprepocnemis plorans, e.g., MASsA et al. (2013), see Fig. 4). In the case of Xya pfaendleri, two hypotheses can be provided to explain this unusual finding. The species is either (i) native to Dalmatia, but is very rare, and here it was observed because a part of the population had arrived from some neighbouring habitat or (ii) it has been imported from the cities of the Pannonian region (cities in Northern Croatia, such as Varaždin and Čakovec), which export plant material to Dubrava on a regular basis. When it comes to the occurrence of $R$. annulata in Slovenia, we can assume that the record is probably the result of a similar scenario as those in Croatia, i.e., the species has been introduced via plant material, although no garden centre is in proximity of the observation. It has happened several times in the past and will surely happen again in the future, as many new species have been introduced in this way (Bardet \& Boitier, 2006; Reinhardt \& Köhler, 2014; Essl \& ZunA-KratKy, 2021).

We think that $R$. annulata and E. plorans will spread in the coming seasons either through purchases of plant material containing the eggs of the species, or from natural expansion to and through Dalmatia due to global warming (we have a similar expectation for the spread of $R$. annulata in Slovenia). For Xya pfaendleri our expectations are somewhat different - we believe that they will not spread as easily and rapidly as the other two mentioned species due to the lack of moisture in the neighbouring regions of Dalmatia. The lack of moisture represents harsh habitat conditions, and this water-dependent species may be unable to migrate even over small distances. It is important to look for these species in the surrounding area in order to monitor its potential spread into the natural habitats.

\section{ACKNOWLEDGEMENTS}

Thanks to Niko Kasalo and Josip Skejo for the literature, help with identification, manuscript and figures' preparation. And again, special thanks to Josip Skejo for thorough help in drafting this paper and providing relevant studies.

Received October 20, 2021

\section{REFERENCES}

Bardet, O. \& Boitier, E., 2006: Rhacocleis annulata Fieber, 1853, espèce nouvelle pour la France (Orth., Tettigoniidae). Bulletin de la Société entomologique de France 111(4), 474.

Bellmann, H., Rutschmann, F., Roesti, C. \& Hochkirch, A., 2019: Der Kosmos Heuschreckenführer, Die Heuschrecken Mitteleuropas und die wichtigsten Arten Südosteuropas. Kosmos, 320 pp.

Buzzetti, F. M., Hochkirch, A., Massa, B., Fontana, P., Kleukers, R. \& Odé, B., 2016: Rhacocleis annulata. The IUCN Red List of Threatened Species 2016, e.T44698038A70739760. (downloaded on 16 October 2021).

Essl, F. \& ZunA-Kratky, T., 2021: The checklist of alien orthopterans (Orthoptera) and mantises (Mantodea) in Austria. BioInvasion Records 10 (in press)

Felix, R., Heller, K. G., Odé, B., Rebrina, F. \& Skejo, J., 2020: Island mysteries in the spotlight: Barbitistes kaltenbachi and Rhacocleis buchichii, the only bush-cricket species endemic to Croatia (Orthoptera, Tettigoniidae). ZooKeys 936, 25-60.

Gomboc, S. \& ŠEgula, B., 2014: Pojoče kobilice Slovenije// Singing Orthoptera of Slovenia EGEA, Zavod zanaravo, Ljubljana, 240 pp.

Hochkirch, A., Nieto, A., García Criado, M., Cálix, M., Braud, Y., Buzzetti, F. M., Chobanov, D., Odé, B., Presa Asensio, J. J., Willemse, L., Zuna-Kratky, T., Barranco Vega, P., Bushell, M., 
Clemente, M. E., Correas, J. R., Dusoulier, F., Ferreira, S., Fontana, P., García, M. D., Heller, K-G., Iorgu I. Ș., Ivković, S., Kati, V., Kleukers, R., Krištín, A., Lemonnier-Darcemont, M., Lemos, P., Massa, B., Monnerat, C., Papapavlou, K. P., Prunier, F., Pushkar, T., Roesti, C., Rutschmann, F., Şirin, D., Skejo, J., Szövényi, G., Tzirkalli, E., Vedenina, V., Barat Domenech, J., Barros, F., Cordero Tapia, P. J., Defaut, B., Fartmann, T., Gomboc, S., Gutiérrez-Rodríguez, J., Holuša, J., Illich, I., Karjalainen, S., Kočárek, P., Korsunovskaya, O., Liana, A., López, H., Morin, D., Olmo-Vidal, J. M., Puskás, G., Savitsky, V., Stalling, T. \& Tumbrinck, J. 2016a: European Red List of Grasshoppers, Crickets and Bush-crickets. Publications Office of the European Union, Luxembourg, 94 pp.

Hochkirch, A., Willemse, L. P. M., Szövényi, G., Rutschmann, F., Presa, J. J., Krištín, A., Kleukers, R. \& Chobanov, D. P., 2016b: Eyprepocnemis plorans. The IUCN Red List of Threatened Species 2016, e.T16084602A74492960. (Downloaded on 16 October 2021).

Hochkirch, A., Zuna-Kratky, T., Puskás, G., Ivković, S., Iorgu, I. Ș., Krištín, A., Chobanov, D. P., Kočárek, P., Skejo, J., Lemonnier-Darcemont, M., Willemse, L. P. M., Rutschmann, F., Kleukers, R., Presa, J. J. \& Szövényi, G., 2016c: Xya pfaendleri. The IUCN Red List of Threatened Species 2016, e.T68486392A74625442. (Downloaded on 16 October 2021).

HaRz, K., 1969: Die Orthopteren Europas I.//The Orthoptera of Europe I. In: Series Entomologica. Vol. 5. Dr. W. Junk, The Hague, pp. 1-749.

Harz, K., 1975: Die Orthopteren Europas II.//The Orthoptera of Europe II. In: Series Entomologica. Vol. 11. Dr. W. Junk, The Hague, pp. 1-939.

Holuša, J. 2014: Record of Xya pfaendleri Harz, 1970 (Orthoptera: Tridactylidae) in the Czech Republic: evidence that the species is spreading north. Annales de la Société entomologique de France (NS) 50(2), 177-182.

Kaláb, O., Pyszko, P. \& KočÁrek, P., 2021: Estimation of the Recent Expansion Rate of Ruspolia nitidula (Orthoptera) on a Regional and Landscape Scale. Insects 12(7), 639.

Martinović, M., Ćato, S., Lengar, M. \& Skejo, J. (under review): First records of three exotic giant mantid species on the Croatian coast. Journal of Orthoptera Research.

Massa, B., Fontana, P., Buzzetti, F. M., Kleukers, R. M. J. C. \& Odé, B., 2013: Orthoptera. 48. Fauna d'Italia. Calderini, Milano, 563 pp.

Monnerat, C., Gurcel, K., Magnouloux, M. \& Dunant, F., 2020: Premières observations de Rhacocleis annulata Fieber, 1853 en Suisse et en Haute-Savoie limitrophe (Orthoptera: Tettigoniidae). Entomo Helvetica 13, 37-40.

Pavlović, M., 2019: Egyptian locust (Anacridium aegyptium) (Acrididae: Cyrtacanthacridinae) in the Pannonian part of Croatia. Articulata 34, 95-100.

Pavlović, M., Sule, D. \& Skejo, J., 2020: Pregled skakavaca i zrikavaca (Insecta: Orthoptera) Šolte i usporedba s faunom Brača. Bašćina 29, 120-134.

Reinhardt, K. \& Köhler, G., 2014: A locust Acanthacris ruficornis (Fabricius, 1787) in a flower shop of Tübingen, Germany (Acrididae: Cyrtacanthacridinae). Articulata, 29, 93-97.

Skejo, J., Rebrina, F., Szövényi, G., Puskás, G. \& Tvrtković, N., 2018: The first annotated checklist of Croatian crickets and grasshoppers (Orthoptera: Ensifera, Caelifera). Zootaxa 4533(1), 1-95.

Stalling, T., GJeldum, A., Milat, T. \& Pavlović, M., 2021: Myrmecophilus fuscus Stalling, 2013: new for the fauna of Croatia (Orthoptera: Myrmecophilidae). Natura Croatica 30(1), 257-261.

Szövényi, G. \& Puskás, G., 2012: A contribution to knowledge concerning the Orthoptera fauna of the Slavonian range (NE Croatia) with the first record of some species in Croatia. Natura Croatica 21(2), 403-418.

van der Heyden, T., 2021: First records of Hierodula transcaucasica Brunner von Wattenwyl, 1878 in Slovenia and Spain (Mantodea: Mantidae). Arquivos Entomolóxicos (24), 265-266.

Vujić, M. D., Ivković, S., Rekecki, T., Krstić, D., Stanković, V., Đurić, M. \& Tot, I., 2021: A first record of the alien mantis species Hierodula tenuidentata (Mantodea: Mantidae) in Serbia. Acta Entomologica Serbica 26(1), 1-7.

WAGner, W. 2015: First record of Rhacocleis buchichii Herman 1874 (Orthoptera: Tettigoniidae) in Croatian mainland. Entomologia Croatica 19(1-2), 37-41.

Żurawlew, P., Desutter-Grandcolas, L., Szymański, P. \& Herman, D. B., 2020: New records of exotic crickets in Europe: Homoeogryllus species (Orthoptera: Gryllidea: Phalangopsidae). Journal of Orthoptera Research 29, 121-125. 